\title{
Speech without words? An Essay Endeavouring a Probability That the Language of China Has No Words
}

\author{
Halvor Eifring \\ University of Oslo
}

\begin{abstract}
This essay argues that traditional criteria for wordhood do not work well for Chinese. Stress plays a minor role and cannot be used to determine phonological wordhood. There is little or no inflection to help us define the morphological word. Morphological compounds and syntactic word combinations are based on the same structures. Morpheme combinations are seldom absolutely inseparable. Wordlike usage of so-called bound forms is extremely common. It seems natural to conclude that Chinese has no words, only morpheme combinations with varying degrees of cohesion.
\end{abstract}

Keywords: word, morpheme, lexical item, Chinese, compound, syntax vs. morphology. 


\section{The word "word"}

"In the beginning was the Word, and the Word was with God, and the Word was God." We know now that this translation of the opening verse of the Gospel of St. John does not accurately render the Greek text, since the meaning of the Greek word logos is much more complex than that of its English near-equivalent word. Still, its use as a metaphor for something so holy that it is identical with God has placed the word at the very centre of the Western universe.

Outside the religious sphere, words are, in the West, often conceived as the most important building blocks of language. Language may well exist without sounds, as in writing or in the sign languages of the deaf, and a rudimentary language may perhaps exist without sentences. But a language without words seems like a contradiction. As a metaphor, the word is sometimes even used to refer to language as a whole, so that those who feel it as their responsibility to protect their language against what they conceive as corruption often talk about themselves as defenders of the word.

In strong contrast to this, the Chinese did not have a word meaning 'word' until it was introduced from the West. The nearest equivalent, $c i$, whether written 詞 or 辭, could mean a collocation of characters, or speech in general, but never word in the Western sense. It is true that one of the newest Chinese dictionaries, the Hàny ̌̀ dà zidiăn (p. 3957), defines 詞 as "the smallest independent phonetic and semantic unit that may be freely used", which sounds like a word definition taken from modern linguistics. But that is exactly what it is. It is a technical definition that describes what modern Chinese linguists and lexicographers think the term ought to mean. When the same dictionary gives a quotation from the Han dynasty work Shuōwén jiězi (說文解字) as an example of this usage, they attribute

\footnotetext{
${ }^{1}$ This essay is a slightly amended version of a lecture held for a general audience at the University of Oslo on September 17, 1993. The subtitle alludes to the title of John Webb's famous book An Historical Essay Endeavouring a Probability That the Language of the Empire of China is the Primitive Language from 1668. To many modern linguists, I am afraid, the hypothesis that Chinese has no words seems just as remote as the assumption that Chinese is the primitive language that all of mankind spoke before Babel. I do not expect that this little essay is going to convince the skeptic, but I hope it may form the basis for later and more thorough inquiries into the matter.
} 
to the ancient Chinese an understanding of the term that did not become current in China before this century.

Even today 詞 meaning 'word' is very much a technical term, used by linguists and students of foreign languages, its relevance for Chinese still being disputed both by linguists and language teachers (cf. Zhōu 2013). When a European refers to "the word love", a Chinese would rather say "the two characters love", since the Chinese word for love is written with two characters (愛情), corresponding to two syllables in the spoken language (ài-qíng). Even modern Chinese, therefore, does not have an everyday word meaning 'word'.

The fact that the Chinese have not written or spoken about words does not necessarily mean that their language does or did not have words. But it is legitimate to ask the question: Is the word a universal linguistic entity, or are there languages that do not have words in the traditional sense? In the following, I shall argue that Chinese, as contrasted with what I consider typical word languages like Norwegian and English, does not have the linguistic unit called a word.

\section{Word boundaries in traditional writing}

In languages written with the Roman alphabet, word boundaries are marked by spaces. There are many inconsistencies, as witnessed by the contrast between fingerprint written as one word and finger mark written as two. Even linguists seem to be unable to agree on the spelling of some compounds, and one and the same word (if it is one word) has been written in at least three different ways by prominent scholars: word formation in two words, word-formation with a hyphen, and wordformation written as one word. The same varieties are found in expressions as common as flower pot/flowerpot/flowerpot. In spite of such inconsistencies, however, the marking of word boundaries is felt by us to be a necessary tool without which almost any written text would be virtually unintelligible.

In Chinese, things are different. Each written symbol represents not a single vowel or consonant, as in English, but a syllable with a given set of meanings. These characters are written continuously, without any indications of word boundaries. In many texts, all lines contain the same number of characters. When the line is filled, a new 
line starts, even if this means breaking a fixed expression into two. No hyphen is needed to let 愛 $a ̀$ at the end of one line combine with 情 qing at the beginning of the next to form the word (if that is what it is) 愛情 ài-qíng meaning 'love'.

Of course, the fact that word boundaries are not marked in Chinese does not necessarily imply that Chinese does not have any words. There is hardly any doubt that Latin can be usefully described as having words. However, from the fourth to the tenth century virtually all Latin texts were written in an even more extreme form of scriptura continua than Chinese. Not only were word boundaries unmarked. Even syllable boundaries had no impact on line division. Each line was filled with letters to its margins, breaking in the middle of a syllable if necessary (cf. Levinson 1985:18ff.).

The fact that Chinese writing does not mark word boundaries, therefore, does not prove that Chinese has no words.

\section{Word boundaries in romanized texts}

One might wonder whether the word, like many other grammatical constructs, is not some kind of Indo-European invention with little relevance for other language families. But if Edward Sapir (1921) is right, this does not seem to be the case. The word seems to be an easily identifiable unit also in languages that are, as far as we know, unrelated to the languages of Europe. According to Sapir, "the naïve [American] Indian, quite unaccustomed to the concept of the written word, has nevertheless no serious difficulty in dictating a text to a linguistic student word by word" (p. 33f.). His experience with Indians taught to write their own language confirms this:

Twice I have taught intelligent young Indians to write their own languages according to the phonetic system which I employ. They were taught merely how to render accurately the sounds as such. Both had some difficulty in learning to break up a word into its constituent sounds, but none whatever in determining the words. This they both did with spontaneous and complete accuracy. In the hundreds of pages of manuscript Nootka text that I have obtained from one of these young Indians the words ... are, practically without exception, isolated precisely as I or any other student would have isolated them." (p. 34n) 
If such anecdotes prove the psychological reality of the word, however, they not only show that some American aboriginal languages have words, but also, it seems, that Chinese does not. When Chinese is romanized (written with the Roman alphabet), it is usually written syllable by syllable rather than word by word. In the 1920's, the linguist Lí Jinnxī tried to oppose this habit by introducing the slogan “write words connectedly" (詞類連書, cf. Chao 1968:186n). In 1950 another linguist, Lù Zhìwěi, had to admit that there still existed no agreed-upon way of isolating Chinese words, but he still spoke optimistically about a time "thirty or fifty years from now", when "the habit of using words has become common, and ... primary school text materials and newspapers in the vernacular all leave a blank space between words" (Lù 1950:13). Today, 63 years after Mr. Lù's optimistic statement, the romanized passages of most Chinese textbooks still leave a blank space, not between words, but between syllables. This is also often the case in romanized text occurring on signs and prescriptions for use. In other cases, no blank spaces are included at all, resulting in the same type of scriptura continua that was used in Latin before the tenth century. One may even see long and intricate romanized prescriptions for use on tubes of Chinese medicine without a single blank space to indicate word boundaries. Sometimes even two letters that in combination represent a single sound, such as sh representing a retroflex sibilant, occur on different lines, without a hyphen. The principles of scriptura continua are sometimes also applied to English, as on the plastic bags found in some Chinese hotels, on which are written "forsanitarynapkins" and "pleaseleaveitinthewastebasket".

One might argue that Chinese are unable to parse a romanized sentence into words not because they do not have words, but because they do not care. Romanized texts are usually written by people who are utterly uninterested in what they write, since they just do it in order to comply with government regulations. Except when applied to English, their failure to parse the texts into words has no practical consequence, since those Chinese who can read the transcription system used are certainly much more likely to read the same text written with Chinese characters. The fact is, however, that even people who do care, such as linguists, cannot seem to agree on how to parse one and the same text into words either. The following sentence 
may be parsed as everything from five to eleven words according to the principles employed by different linguists:

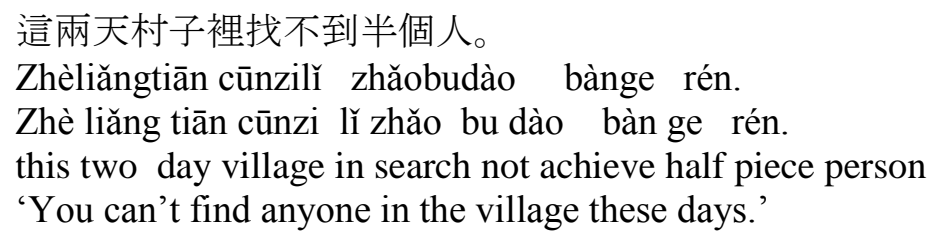

While this does not prove that Chinese lacks words, it indicates clearly that words, if they are found at all, are much less readily separable in Chinese than in Norwegian and English.

\section{Word, morpheme and lexical item}

The word is not the smallest meaningful unit of a language. To take the word outstanding, it consists of at least three smaller meaningful units, called morphemes: out, stand and ing. ${ }^{2}$ The primary difference between this sequence of morphemes and the sequence of morphemes found in e.g. drink juice lies in the high degree of cohesion between its elements: out, stand, and ing are tightly knit together, while drink and juice are much more loosely knit together. Therefore, outstanding is one word, while drink juice is two.

The cohesion between meaningful elements is a matter of degree. Sometimes what were originally sequences of individual words gradually evolve into tightly knit units, into single words. For instance, Latin res publica 'public matters' has become English republic, and early Old Norse sýna sik 'to show oneself' has become modern Norwegian synes 'to think; to feel; to find'. In word languages like Norwegian and English, there is one point on this scale from low

\footnotetext{
${ }^{2}$ In the analysis of European languages like English, this way of dividing words into segmental morphemes is now more or less obsolete (cf. Endresen 1988:138ff.), but is retained here both for reasons of clarity and because it seems less problematic when applied to Chinese. Some linguists retain the term morpheme, but redefine it to be able to account for so-called non-segmental morphemes. For instance, Katamba (1993:24) defines the morpheme as "the smallest difference in the shape of a word that correlates with the smallest difference in word or sentence meaning or in grammatical structure". If it is true that some languages do not have words, however, this definition is highly problematic.
} 
to high cohesion at which the combined elements start to behave like words. Once they pass this point, this has phonological, morphological as well as syntactic consequences. It is not given, however, that all languages distinguish words from non-words as strictly as Norwegian and English do. In Chinese, I am arguing, there is no such single point. There are many phonological and grammatical effects of different degrees of cohesion. But these effects appear at different points along the scale and do not cluster around any one specific grammatical unit like the word.

We know, of course, that the correlation between phonologically and grammatically determined words is not absolute in Norwegian and English either. As we shall see, however, in Chinese such lack of correspondence is the rule and not the exception, not only between phonological and grammatical words, but also within each of these groups.

Note that we are not discussing whether all languages have lexical items consisting of more than one morpheme, which is beyond doubt. But lexical items need not be single words, neither in Norwegian, English nor Chinese. The Norwegian expression vandre heden (lit. 'wander away') and the less solemn English expression kick the bucket are both lexical items, since their meaning is not deducible from their constituent elements. Both expressions, however, consist of more than one word. When we ask if a given lexical item is a word, we ask whether it behaves phonologically, morphologically and syntactically like the idiom kick the bucket or like the single word die. In the following, I shall examine Norwegian, English and especially Chinese according to some of the criteria often used to determine wordhood.

\section{Phonological criteria}

In the languages of the world, wordhood may affect phonology in at least two ways. The word may be the scope of rules for vowel harmony, as in Turkish and Finnish, and it may be the most central unit in stress assignment. Since neither Norwegian, English nor Chinese has vowel harmony, only stress and related phenomena will be considered here. 
In Norwegian, wordhood has phonological consequences, since it may affect the stress pattern of a given lexical item. The rule is that one word cannot contain more than one main stress. Thus, god gutt 'a good boy' is two words and has two main stresses, while godgutt 'a good boy' is one word and has only one main stress (on the first syllable). There are a few adverbs, like фyeblikkelig 'immediately', sannelig 'truly', akkurat 'just', and allerede 'already' that may, in emphatic positions, have two main stresses: on the first and third syllables. There are even a few adjectives, like ufordragelig and uutholdelig 'intolerable, unbearable' that may, under extreme emphasis, have three main stresses: on the first, second and third syllables. Such expressive use of stress, however, does not disprove the general pattern, according to which Norwegian words have either one main stress or no main stress at all.

To what extent wordhood affects stress in English is a more complex question. Most compound words have primary stress on the first constituent, so that a darkroom is one word, while a dark room is two. The exceptions are usually compounds consisting of an adjective/noun plus an adjective, in which the second constituent is semantically dominant: psycho-somatic, age-old (cf. Quirk et al. 1985:1568ff.). If stress is used to define wordhood, however, the fixed and indivisible expression science fiction is two words and not one. One might argue, instead, that science fiction is one word, and that stress is no reliable marker of wordhood in English.

In Chinese, stress distinctions are much less obvious than in both Norwegian and English. The main distinction is between toned and toneless syllables, and all the syllables in a word may be toned. There are also distinctions in stress among the toned syllables of otherwise homonymous lexical items. For instance, the noun bùxing 步行 'walk by foot' is pronounced with the main stress on the first syllable, while the negated verb bù xing 不行 'it is not OK' has its main stress on the second syllable (stressed syllables underlined). In many cases, however, stress distinctions are extremely subtle, so subtle that many excellent linguists and phoneticians have declared them non-existant. It is symptomatic when one of the minimal pairs rendered by Harbs-meier (1992) as fājué 發覺 'become aware, discover' vs. fäjué 發掘 'unearth', is given exactly the opposite stress distribution in one of the few dictionaries that have attempted to 
assign stress to lexical items, Oshanin (1983 vol. 3 p. 1047 and 1050). ${ }^{3}$ While it is clear that some stress distinctions do exist in Chinese, they play a very minor role, and it is probably impossible to apply word criteria based on stress to Chinese.

The Russian scholar M. K. Rumjancev (1960) argues that his experimental work indicates an intonational difference between what he regards as word combinations and compound words (cf. Lyovin 1978). Read in their literal meaning as word combinations, the phrases 嘴硬 zul̆ yìng 'mouth [is] hard', 黑版 hēi băn 'a black board' and 拖 船 tuō chuán 'to pull a boat' all have distinct intonational features that mark the different syntactic structures on which they are built. Read in their idiomatic meaning as single lexical items meaning 'impudent', 'blackboard' and 'barge', respectively, this intonational distinction disappears. He also finds that word combinations have longer total duration than compound words. And while the second element is longer than the first in a compound word, the reverse is true in a word combination. It is not clear, however, if these features are markers of wordhood. Some of the results reported by Rumjancev indicate that intonational distinctions are gradient, with no absolute values. In that case, they may mark degrees of cohesion without indicating a specific point on the scale from low to high cohesion at which a combination of morphemes becomes a word. More experimental research is needed to determine the nature of what he considers to be word intonation.

According to the famous linguist Yuen-Ren Chao (1968:147), $\mathrm{Wu}$ dialects have different tone sandhi (combining forms of tones) within words and across word boundaries. Thus, in the Suzhou dialect both 放參 'puts in ginseng' and 放生 'sets free a living being (for religious or similar reasons)' both consist of words that are pronounced fang with the tone contour [513] and sen with the tone contour [45] when read by themselves. When the two words are combined, however, the resulting tone contours are different in the two cases: $[51+45]$ in the first case and $[45+42]$ in the second. Presumably this is because the latter example is a word, while the former is a phrase. From this single example, however, it is difficult to tell whether the tone sandhi differences are due to wordhood or simply idiomaticity. There is no doubt that 放生 is an idiomatic expression, but is it one word? Structurally, it is a verb meaning 'to set free'

\footnotetext{
${ }^{3}$ For an overview of such dictionaries and word lists, see Visted (2012).
} 
followed by an object meaning 'life', and without more information about its behaviour in the Suzhou dialect it is impossible to tell whether it is one word or two. If it is, as one may suspect, a two-word idiom rather than a single word, this goes to show that the important distinction is not between word and non-word, but between different degrees of idiomaticity.

Both in Norwegian, English, and Chinese, pausing is often mentioned as a criterion for a word boundary. Pausing is possible between words, but not, except for hesitation, within words. This criterion is not always easy to employ, however, since the words of the same sentence are usually uttered more or less in succession, and the insertion of pausing often feels awkward even between words. It is also sometimes possible to insert a pause in a compound word.

In Chinese, it sometimes seems that rhythmic principles influence judgements concerning word boundaries. In romanized texts, there is a tendency to write di- and trisyllabic lexical items as one word, while items of four syllables are written as two. Thus, the official way of writing The People's Republic of China in romanized Chinese is Zhōnghuá rénmín gònghéguó. Similarly, in the dictionary Shídài Hànyǔ cídiăn, 玻璃紙 'window paper' is romanized as bōlizhř in one word, while 玻璃纖維 'glass fibre' is romanized as bōli xiānwéi in two words. The reasons for this parsing principle, which does have some intuitive appeal, seem to be purely rhythmic. It has nothing to do with the traditional criteria for wordhood. It creates some problems in cases like 象形文字論 xiàngxíng wénzì lùn '(philosophical) symbolism' (lit. 'pictographic character theory'), in which rhythmic principles indicate that 文字 wénzì and 論 lùn belong to the same word, while 象形xiàngxing is a separate word. Since 論 lùn is clearly modified by the whole expression 象形文字 xiàngxing wénzì, Xiàndài Hànyǔ cídiăn (p. 1249) chooses instead to treat 象形 文字論 xiàngxíng wénzì lùn as three words. In the case of its synonym 符號論 fúhàolùn, however, the same problem does not arise.

\section{Morphological criteria}

In word languages, wordhood may affect morphology in at least two ways. First, it has inflectional consequences, since a compound word 
may only be inflected as a whole. Second, it has structural consequences, since the internal structure of compounds often differs from the structure of word combinations.

\subsection{Inflection}

In both Norwegian and English, no part of a word may be inflected, only the word as a whole. In the Norwegian word nyttår 'New Year', the first element is only apparently inflected for gender (containing the suffix - $t$ marking both neuter and singular), as is clear from the fact that the plural form is unchanged: there exists no *nyear (with the plural marker $-e$ rather than the singular neuter marker $-t t)$. One possible exception is the occasional use of the word marxismenleninismen 'Marxism-Leninism', in which both elements contain the definite singular suffix -(e)n. In English the exceptions are somewhat more numerous, as exemplified by words like menservants, women priests, and gentlemen farmers. In general, however, English observes the same rule as Norwegian.

In Chinese, inflection is extremely scarce. The aspect markers le 了 (perfective), guò 過 (experiential), and zhe 著 (progressive) are often considered inflectional suffixes. However, to judge from the fact that one single suffix may modify two coordinated verbs in phrases like tíchu hé zhíxing le 提出和執行了 'took up and carried through', it resembles a clitic word rather than an inflectional suffix. In some non-standard variants of Chinese the experiential marker guò 過 may even occur after the object: Wǒmen méi lái zhèli guò 我們沒來這裡過 'We have never been here' (lit. 'we not-have come here guò'). Even if aspect markers are considered inflectional suffixes, however, they most often occur only once even in a collocation of several separate verbs, making it impossible to use them to distinguish between composite verb phrases and compound verbs.

The collective plural marker men 們, which is only used with human nouns and pronouns, is also often considered an inflectional suffix. Like the aspect markers, however, it may also modify two separate nouns simultaneously, as in xiānsheng hé tàitai men 先生和 太太們 'Sirs and Madames'. It resembles, therefore, a clitic word rather than an inflectional suffix. 


\subsection{Internal structure}

In both Norwegian and English, the internal structure of compounds is different from the structure of syntactic phrases consisting of more than one word. While some compounds are simply contracted forms of syntactic phrases, such as nyttår ('New Year', from nytt 'new' and år 'year') and godtfolk ('good people', from godt 'good' and folk 'people') in Norwegian and cleaning woman and best man in English, others are structurally different. The combinations that are possible in compounds are often impossible in phrases, such as noun plus noun in Norwegian (kjellertrapp 'basement stairs') and uninflected verb plus subject noun in English (playboy). In addition comes the fact that the first constituents in compounds often have special forms, such as barnepass (child-care, cf. barn 'child'), arbeidsliv ('working life', cf. arbeid 'work'), fotball ('football', with a short $o$ rather than the long $o$ of fot 'foot') in Norwegian and electromagnet or Anglo-Saxon in English.

In Chinese, the internal structure of what might be conceived as compound words is in most cases exactly the same as the structure of syntactic phrases. This is one of the main reasons why it is often so difficult to distinguish between compounds and phrases in Chinese.

One particularly clear example is the pattern consisting of a verb with an object. In chī tǔdour 吃土豆兒 'to eat potatoes', we have a clear case of verb-object as a free syntactic construction. Both the verb and the object may be used freely on their own, there is no idiomatization, and the object may be moved in front of the verb or separated from it by other elements. In chì fàn 吃飯 'to eat rice; to eat; to make a living', the verb and the object may also be used on their own and move about in the sentence independently of each other. In this case, however, there are two idiomatic meanings in addition to the literal meaning. In chī xiánfàn 吃閒飯 'to be a loafer' (lit. 'eat idle rice') the verb is free and the object at least semi-free, but in this case there is only an idiomatic meaning and no literal one. Again, however, the object may be moved before the verb or separated from it by other elements. In chì jīng 吃驚 'to be startled' (lit. 'eat shock') the verb is free, but the object bound, there is again only an idiomatic meaning, and while it is fully possible to separate the verb and the object by means of aspect particles or modifications to the object, it is not possible to move the object before the verb. Finally, in chī xiāng 吃香 
'to be popular' (lit. 'eat fragrance') the verb and the object are strictly inseparable. Where does the syntactic phrase end and the compound word start?

Because of their semantic transparency, what has already become inseparable verb-object compounds may also be reinterpreted as verb-object phrases, often for jocular purposes. For instance, in géming 革命 'revolution; to participate in the revolution' (lit. 'cut-off mandate') the verb and the object is sometimes separated from each other in expressions like gé tā de ming 革他的命 (lit. 'cut-off his mandate'), which has a double meaning, since ming 命 also means 'life'.

While the tendency is for idiomatic verb-object phrases to gradually develop into compound verbs, it also happens that compound verbs that are originally not verb-object compounds are interpreted as verb-object phrases. The standard example is tiào wǔ 跳 舞 'to dance', originally composed out of two verbs meaning 'to jump' and 'to dance', respectively, but now interpreted as a verbobject phrase, wǔ 舞 having become a free noun meaning 'a dance'. The linguist Lù Zhìwěi (1950:26) mentions more recent non-standard formations like the following:

後了悔了 hòu-le huì le for 後悔了 hòuhuì le 'regretted' (hòuhuǐ 後悔 [lit. 'after-regret'] 'to regret'; le 了 [perfective aspect marker])

演一次講 yăn yí cì jiăng for 演講一次 yănjiăng yí cì 'to give one lecture' (yănjiăng 演講 [lit. 'perform-speak'] 'to give a lecture' yí cì 一次 'one time, once')

貪了一點污 tān-le yì diăn wū 'embezzled a little [money]', from 貪污 tānwwū [lit. 'greedy-corrupt'] 'to embezzle'

I have myself heard people say jìng wán zuò 靜完坐 before correcting themselves to jìng-zuò wán 靜坐完 'finished meditating' (jìng-zuò 静 坐 [lit. 'still-sit'] 'to meditate' wán 完 [a resultative complement marking completion]).

In verbs followed by resultative complements there are three types. In the most elaborate type, the verb and the complement are separated by the grammatical marker de 得, and the complement may be a full clause, as in the following sentence: 


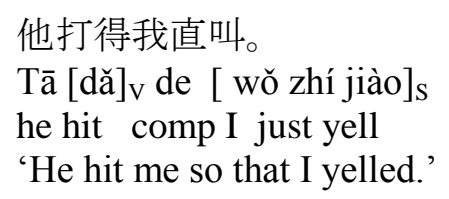

In such cases, the resultative complement clearly does not belong to the same word as the verb. In jocular contexts what is originally inseparable compound verbs is sometimes treated as if they belonged to this type, as when the adjectival verb luòhòu 落後 'backward' is expanded into luò de hén hòu 落得很後 'be very backward' (Harbsmeier 1992:268).

At the other extreme are cases where the verb and the resultative complement are absolutely inseparable. This is the case in expressions like tuīguăng 推廣 'to spread' (lit. 'push wide') and jiănshăo 減少 'to decrease' (lit. 'reduce little'). If there are words in Chinese, such expressions are certainly single words, not word combinations.

In the medium type, a verb is directly followed by a verbal complement, as in dă yíng 打贏 'to win' (lit. 'hit win'), chī băo 吃飽 'to have one's fill' (lit. 'eat full'), in which case nothing can usually intervene between the two verbs except the potential markers de 得 and bù 不, as in chì de băo 吃得飽'to be able to have one's fill' and chī bu băo 吃不飽'to be unable to have one's fill'. It is commonly said that $d e$ 得 and bù 不 are infixes, and that this type is a one word construction. But it is equally possible to say that $d e$ 得 and bù 不 are clitic words that separate the main verb and the complement, especially since both de 得 and bù 不 are used as clitics in other similar functions. In jocular style, also other elements may occur between the two verbs, as in chì le ge dà băo 吃了個大飽 'really had his fill' (lit. 'ate a big full'). It also happens that compound verbs that do not belong to this group are treated as if they did, as when the famous author Lŭ Xùn writes jué bu dìng 決不定 'unable to decide' (from juédìng 決定 'to decide', Nàhăn p. 111).

A similar type is the directional complement construction. In this construction, a motion verb is followed by a complement consisting of a verb of type 1 or a verb of type 2 or both: 
Type 1: shàng 上 '[come/go] up', xià 下 ‘[come/go] down', jìn 進 '[come/go] in', chū 出 '[come/go] out', huí 回 '[come/go] back', guò 過 '[come/go] across', $k \bar{a} i$ 開 '[come] apart', and q̌̌ 起 '[come] up (from the ground)'.

Type 2: lái 來 ('come', indicating movement towards the speaker) and qù 去 ('go', indicating movement away from the speaker).

All complements of type 1 may combine with both complements of type 2, except $k \bar{a} i$ 開 and $q \check{\imath}$ 起, which may only combine with lái 來, not with qù 去. The resulting structures are not indivisible. For instance, ná chù lái 拿出來 'take out' may combine with the object yì běn shü 一本書 'one book' in three different ways:

ná le yì běn shū chū lái 拿了一本書出來 (with the perf. marker le 了) ná chū yi běn shū lái 拿出一本書來 ná chū lái yi běn shū 拿出來一本書

Directional complements are not always as flexible as this, but they may always be split up by an object. Like the medium type of resultative complements described above, they may also be split up by the potential markers de 得 and bù 不: ná de chù lái 拿得出來 'able to take out', ná bu chū lái 拿不出來 'unable to take out'. To judge from this, they are not one-word constructions. On the other hand, the fact that the object may follow the whole construction seems to indicate that the whole construction acts as a single verb.

In the case of attributive constructions, it is customary to say that wherever de 的 may be inserted without a change in meaning, as in xinn (de) fángzi 新(的)房子 'new house', we have two words, while in cases where the insertion of de alters the meaning, as in xiăo m̌̆ 小 米 'millet' as opposed to xiăo de mǐ 小的米 'short-grained rice', we have one word. However, this does not seem to be a test of wordhood, but of idiomaticity. And something does not have to be a word to be idiomatic, nor does it have to be idiomatic to be a word.

There is also a gradient distinction between what might be conceived as subject-predicate compounds and syntactic subjectpredicate constructions. For instance, when the expression tiān liàng 天亮 'to dawn' (lit. 'heaven bright') occurs in an adverbial clause 
with $y \bar{l}$ - 'once, as soon as', this conjunction may occur before the whole expression, treating it as what seems to be a verb, or it may intervene between tiān 天 and liàng 亮, treating it as a syntactic subject-predicate construction. The gradience of this distinction is especially clear in the case of constructions with a so-called secondary subject. A typical example of the compound type is niánqing 年輕 'young' (lit. 'year light'), which is absolutely indivisible except in alternative questions (nián bu niánqīng 年不年輕). The nearsynonymous expression niánjì qingqing de 年紀輕輕的 (lit. 'age light sub') also seems to be indivisible, and adverbs like $d \bar{o} u$ 都 'all' have to precede the whole expression instead of splitting the subject and the predicate apart: tāmen dōu niánjì qingqing de 他們都年紀輕輕的 is fully acceptable, while ?? tāmen niánjì dōu qīngqīng de ??他們年紀 都輕輕的 is, at best, dubious. The secondary subject niánji 年紀 may, however, be made into the head of a subordinative construction with de 的: tāmen de niánjì qingqing de 他們的年紀輕輕的. In this case, niánjì 年紀 and qingqing de 輕輕的 belong to different main constituents and cannot count as one word. In another nearsynonymous expression, niánjì hěn qīng 年紀很輕 (lit. 'age very light'), adverbs like $d \bar{o} u$ 都 may intervene freely between the subject and the predicate: tāmen niánjì dōu hěn qīng 他們年紀都很輕. Again, the secondary subject may be made into the head of a subordinative construction with de 的: tāmen de niánjì (dōu) hěn qīng 他們的年紀( 都)很輕. The whole expression niánjì hěn qīng 年紀很輕 may also, however, be treated as the predicate of tāmen 他們, as is clear from the fact that it may just as well be preceded by dōu 都: tāmen $\underline{\text { dōu }}$ niánjì hěn qīng 他們都年紀很輕.

In the case of so-called synonym compounds (like péngyǒu 朋 友 'friend' from péng 朋 'friend' and yǒu 友 'friend') and antonym compounds (like dàxiăo 大小 'size' from dà 大 'big' and xiăo 小 'small'), there seems to exist no corresponding syntactic structure. This might be taken as a sign that the word level is, after all, of some significance, since at least one type of morpheme combinations only occurs word-internally. However, all synonym and antonym compounds are strongly idiomaticized disyllabic expressions. The relevant restriction does not seem to take account of word boundaries, 
but rather of the number of syllables allowed. Furthermore, neither type is productive in Modern Chinese and can hardly be used to argue for the existence of a word level in the modern language.

Reduplication might also be seen as a process restricted to occur within words. Again, however, the number of syllables seems to be a more important factor than the alleged existence of word boundaries. Nominal expressions have to be monosyllabic to allow reduplication: yéye 爺爺 'paternal grandfather' and dòudou 豆豆 'beans' (in children's language) as opposed to the unreduplicable lăoye 老爺 'maternal grandfather' and tǔdòu 土豆 'potato'. Verbal expressions have to be either monosyllabic or disyllabic to allow reduplication: gāogāo (de) 高高(的) 'high, tall', gāogāoxingxing (de) 高高興興(的) 'happy', láiláiqùqù 來來去去 'come and go'. In the case of disyllabic expressions, which are usually also dimorphemic, the collocation of morphemes has to be strongly idiomatic. In the iterative type exemplified by láiláiqùqù 來來去去, however, it is not obvious that we have to do with one word and not two (cf. Lì 1984:378ff.).

\section{Syntactic criteria}

The syntactic criteria for wordhood are often considered to be most important. The most commonly cited criterion regards the fact that a word is an indivisible unit whose constituent parts may not be separated or moved on their own. Another criterion often discussed is the requirement that the word is a free form (a form which may constitute an utterance of its own).

\subsection{Inseparability}

The arguably most important syntactic criterion for a word regards the inseparability of its constituents. Constituents of a single word may not be moved away from each other, and it is impossible to insert anything in between them. If this is taken to be the main criterion for wordhood, science fiction is one word and not two. Its two main constituents may not be moved away from each other or separated by other linguistic elements. On the basis of this criterion, Otto Jespersen (1924:95) argues that German stattfinden 'take place' is two words rather than one, since we also have stattzufinden 'to take place' and es 
findet nur selten statt 'it only rarely takes place'. In Norwegian and English, the only exceptions to this rule occur in syntactically coordinated compounds with shared second constituent, as in Norwegian post- og bankvesenet 'postal services and banking' or English record-and cassette-player.

In Chinese, the inseparability of what otherwise may count as words is violated by a number of syntactic and morphological processes.

First, all polysyllabic verbs (including adjectival verbs) may be represented by their first syllable in disjunctive questions. This applies whether the first syllable is a morpheme by itself, as in xǐ bu xĭhuān 喜不喜歡 'like' or is just a meaningless syllable, as in luo bu luōsuo 囉不囉嗦 ‘wordy, troublesome', pián bu piányi 便不便宜 'cheap'. This way of forming questions has spread into Northern Chinese only during the past hundred years or so, but is now extremely common.

Second, reduplication with an intensifying effect affects words syllable by syllable rather than word by word, as in qingqingchǔchŭ 清清楚楚 'clear'. This also applies whether each syllable is a morpheme by itself or is just a meaningless syllable, as $h \bar{u}$ 忽 is in piāopiāoh $\bar{u} h \bar{u}$ 飄飄忽忽 'drifting, uncertain'. The tentative use of reduplication is an apparent exception, since the whole word is repeated: jièshao-jièshao 介紹介紹 'to present, to introduce'. But that is because this is not reduplication at all, since the second occurrence of the verb has been nominalized into a kind of measure word constituting a cognate object: 'to introduce a little'. In adjectival verbs with a negative meaning, the first syllable followed by the syllable $l i$ 里 precedes the whole word: súlisúqì 俗里俗氣 'vulgar'. Again this also applies whether each syllable is a morpheme by itself or is just a meaningless syllable, as in húlihútu糊里糊涂 'confused'. The adjectival verb luōsuo 囉嗦 'wordy, troublesome' even has an intensifying form where the first and the last syllables, each of which is meaningless on its own, are separated by two other syllables: luōlibāsuo 囉里巴嗦.

Third, what otherwise appear to be single words are sometimes separated by the negator bù: bù míng bù bái 不明不白 'unclear; without any reason' (from míngbái 明白 'understand'), bù qīng bù chǔ 不清不楚 ‘unclear' (from qīngchǔ 清楚 'clear'), bù gān bú jìng 
不乾不淨 'fillthy' (from gānjìng 乾淨 'clean'), bù zhé bú kòu 不折不 扣 'fully, one hundred percent' (from zhékòu 折扣 'rebate').

Fourth, the extreme frequency of abbreviated forms both in spoken and written Chinese also points to the relative ease with which so-called words are torn apart. In Western languages, abbreviations by means of initial letters (such as GMT for Greenwich Mean Time) are primarily written language phenomena and only secondarily spoken language phenomena, while abbreviations by means of initial syllables (such as pink for Pinkerton detective) is primarily a slang phenomenon. In Chinese, abbreviations by means of initial syllables are extremely common, both in spoken and written language: tŭgăi 土 改 from tǔdì găigé 土地改革 'land reform', Shìdà 師大 from Shīfàn dàxué 師範大學 'Normal (i.e. Teachers') University’, kēji 科技 from kēxué jìshù 科學技術 ‘science and technology'.

Perhaps related to this is the fact that even originally nonmorphemic syllables may be taken to represent the meaning of a whole polysyllabic morpheme. This resembles the process of abbreviation when it happens to the first syllable, as in pingtán 乒壇 'table tennis court' from pingpāngqiú 乒兵球 'table tennis' and $y \overline{i n g g} \bar{e}$ 賏鳥 哥 'parrot' (lit. 'parrot brother', from the originally indivisible morpheme yingwú 鵙武鳥 'parrot'), while it seems to be a separate phenomenon when it happens to the last syllable, as it has thoroughly done in the so-called indivisible morpheme húdié 蝴蝶 'butterfly', whose last syllable dié 蝶 occurs on its own in many expressions, e.g. diéshè 蝶式 and diéyǒng 蝶泳 for 'butterfly style swimming', diéȳ 蝶衣 'butterfly clothes', and mèngdié 夢蝶 'to dream that one is a butterfly' (a recurrent topic in Chinese culture). The case of the so-called indivisible morpheme bōli 玻璃 'glass' is also telling. Its first part occurs on its own in bōzhuān 玻磚 'glass brick', while its last part occurs on its own in liúli 琉璃 'coloured glaze'.

It is commonly said that sequences of demonstrative plus numeral plus classifier are one-word constructions: zhèliăngge 這兩個 [lit. 'this class two'] 'these two', nàsānge 那三個 [lit. 'that class three'] 'those three'. (The demonstrative may, of course, be left out or included according to the meaning.) The singular numeral $y \bar{\imath}-$ may 
be left out, so that zhège 這個, nàge 那個 and just ge 個 actually imply zhèyíge 這一個, nàyíge 那一個, and yíge 一個, respectively. Otherwise these are almost inseparable. But not quite. Insertion of adjectival verbs like dà 大 and xiăo 小 is in fact quite common: yí dà piàn一大片 'a big slice', yí dà ge xīguā 一大個西瓜 'a big melon'.

Even if one insists that Chinese has words, therefore, it is hard to assert that the word is inseparable. At most, one might say that the separability of the word is restricted.

\subsection{Minimum free form}

The inseparability of the word implies that any utterance must consist of at least one word. Leonard Bloomfield (1933:177ff.) turned this around and said that for something to be a word it must be capable of forming an utterance on its own (it must be a "minimum free form"). In Norwegian and English, this is probably true of most words, though the situations in which the given utterances are spoken must be extremely special for word forms like is and since to act as full utterances. In the cases of the and $a$, it is doubtful whether it is possible at all, but Bloomfield argues that they are words because they are parallel to other words that may occur as full utterances on their own, such as this and that.

Applied to Chinese, Bloomfield's "minimum free form" criterion is problematic. First, the vast majority of function words cannot form utterances on their own. This applies to adverbs like jiù 就 'then', conjunctions like jìrán 既然 'since', coverbs (prepositionlike verbs) like cóng 從 'from', demonstrative pronouns like nă 哪 'which', final particles like $m a$ 嗎 marking yes-no-questions, and arguably also to adnominals like nán 男 'male'. Second, very many words that are minimum free forms have alternative forms that are bound. For instance, chuānghu 窗戶 'window' is free, while chuāng 窗 is bound. The bound form is often the only form that may appear in compounds, such as chuānglián 窗策 'curtain' rather than *chuanghuliánzi 窗戶篻子 (lit. 'window-screen'). The bound form also often appears in fixed syntactic expressions like käi chuāng 開窗 'open the window', which alternates with dăkāi chuānghu 打開窗戶. Some bound forms may act as major constituents in the sentence even outside fixed expressions, as chūn 春 for chüntiān 春天 'spring' in the 
sentence chūn shì zuì měi de jịjié 春是最美的季節 'spring is the most beautiful season'. In all these contexts, bound forms act like ordinary words. To the extent that one operates with words in Chinese, it does not seem natural to deny bound forms word status just because they cannot constitute complete utterances on their own.

\section{Parts of speech}

After a lively debate in the 1950's, it has been generally agreed that Chinese does have parts of speech, so-called word classes (Chinese cílèi 詞類). The question is: If Chinese has no words, what are the "words" that are divided into classes?

It seems clear that prototypical nouns are free and indivisible forms like diànhuà 電話 'telephone' and beeizi 杯子 'cup', and that prototypical verbs are free and (except in alternative questions) indivisible forms like xìhuān 喜歡 'to like' and gàosu 告訴 'to tell'. There are other parts of speech, however, that are prototypically bound, such as classifiers (běn 本 [of books etc.], ge 個 [general]), coverbs (“prepositions": cóng 從 'from', wăng 往 'towards'), and adverbs ( $d \bar{o} u$ 都 'all', hái 還 'still'). Even nouns and verbs may be bound, as in the cases of the noun chuang 窗 'window' and the verb liáo 療 'to treat, to cure'. It is less obvious that expressions with freely separable morphemes may be assigned parts of speech. For instance, shēng qì 生氣 (lit. 'give-birth-to energy') may be classified as a transitive verb in its stative sense 'to be angry' (cf. wǒ hěn shēng-qì zhè jiàn shìing 我很生氣這件事情 'I feel very angry about this matter'), but can hardly be considered a single verb at all in its inchoative sense 'to become angry', since qi 氣 is then clearly an object to the verb shēng 生 (cf. shêng tā de qì 生他的氣 'to become angry with him', lit. 'give-birth-to he sub anger'). To the extent that the existence of parts of speech is an argument for a separate word level in Chinese, therefore, either bound forms have to be considered as words (even the ones that only occur in typical "compounds"), or the word is not the only unit that may be assigned a part of speech, only the largest such unit.

One argument for the wordhood of some Chinese constructions is that they are exocentric. For instance, the two verbs $k \bar{a} i$ 開 'to open, 
to turn on' and guān 關 'to close, to turn off' form the noun kāiguān 開關 'switch'. The latter cannot simply be regarded as a syntactic combination of the former two, it is argued, since verb plus verb can only give a noun on the word level, not on the syntactic level. However, exocentric constructions are also found in more or less fixed expressions that are hardly analyzable as words. One example is the saying nú shì nú, zhǔ shì zhŭ 奴是奴, 主是主 'a slave is a slave, and a master is a master', which consists of two clauses constituting an independent composite sentence with no indication of being strung together as a word. Still, it may act as a predicate, following postsubject adverbs like $y \check{e}$ 也' 'also, even', as in the following sentence:

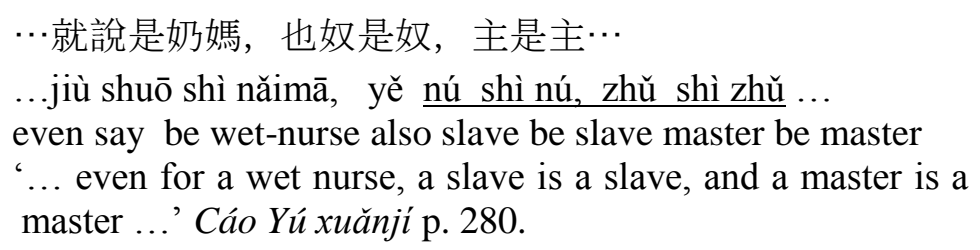

To judge from this, the exocentricity argument for wordhood is not a water-tight argument, although it is only natural that the high degree of idiomaticity required is primarily found in words.

\section{Conclusion}

In Norwegian and English, the phonological, morphological and syntactic criteria described above tend to point towards the same group of linguistic elements, with a few exceptions, in particular regarding the phonologically determined word. In such languages, the notion of the word has an obvious place. Both Norwegian and English are word languages, though word boundaries seem to be somewhat less clear in English than in Norwegian, especially in collocations of noun plus noun, such as science fiction. Norwegian has noun plus noun collocations only in clear compounds that behave like words phonologically, morphologically and syntactically. In English, science fiction behaves morphologically and syntactically like a word, but phonologically like a word combination. 
In Chinese, there seems to be no fixed unit like the word that several different phonological, morphological, and syntactic criteria point towards. It is true that many Chinese lexical items are words by most of the criteria mentioned above, both monosyllabics like rén 人 'person' and gǒu 狗 'dog' and polysyllabics like húdié 蝴蝶 'butterfly' and chibăng 翅膀 'wing'. For a linguist steeped in the Western tradition, therefore, it is not difficult to find lots of words even in Chinese. However, none of the usual word criteria work very well when applied to Chinese. The phonological criteria for wordhood are scarce because of the minor role of stress in Chinese. The inflectional criteria are of little help since Chinese has almost no inflection. The criteria regarding internal structure of compounds vs. word combinations are of little help since both are based on the same structures. The syntactic criterion of inseparability is too often violated to be a good guideline. And the criterion according to which a word must be a minimum free form seems absurd when applied to Chinese, where word-like usage of bound forms is extremely common. It is possible that a word level would be useful in singling out the units (or some of the units) that may be assigned a part of speech, but even this criterion is of little help in most cases in which one might want to distinguish a word from a non-word. On the basis of this evidence, the hypothesis that Chinese does not have words, only morpheme combinations with varying degrees of cohesion, deserves close attention.

\section{References}

Bloomfield, Leonard 1933: Language. New York: Henry Holt.

Cáo Yú xuănjí 曹禺選集. Beijing: Rénmín wénxué 1961.

Chao, Yuen Ren 1968: A grammar of spoken Chinese. Berkeley: University of California Press.

Endresen, Rolf Theil 1988: "Morfologi". In Hanne Gram Simonsen, Rolf Theil Endresen and Even Hovdhaugen (eds.): Språkvitenskap: En elementar innføring pp. 76-140. Oslo: Universitetsforlaget. 
Hànyǔ dà zìdiăn 漢語大字典. Chengdu: Sìchuān císhū/Húběi císhū 1986-90.

Harbsmeier, Christoph 1992: Modern Chinese analytic syntax. Oslo: Department of East European and Oriental Studies, University of Oslo.

Jespersen, Otto 1924 [1955]: The philosophy of grammar. London: George Allen \& Unwin.

Katamba, Francis 1993: Morphology. Houndmills: MacMillan.

Levinson, Joan Persily 1985: Punctuation and the orthographic sentence: A linguistic analysis. Ph. D. dissertation, The City University of New York.

Lì, Wéimín 庽為民 1984: 動詞性 AABB 式初探. In 語海新探 vol. 1 pp. 365-80. Jinan: Shāndōng jiàoyù.

Lù, Zhìwěi 陸志韋 1950 [1990]: 北京話單音詞詞彙. In 陸志韋語言 學著作集 vol. 3 pp. 1-262.

Lyovin, Anatole V. 1978: Review of Rumjancev (1972). Journal of Chinese Linguistics vol. 6 p. 120-68.

Nàhăn 㕧喊. Hongkong: Yayuan 1986.

Oshanin, I. M. 1983: Bol'šoj kitajsko-russkij slovar'. Moscow: Nauka.

Quirk, Randolph, Sidney Greenbaum, Geoffrey Leech \& Jan Svartvik 1985: A comprehensive grammar of the English language. London: Longman.

Rumjancev, M.K. 1972: Ton i intonacija v sovremennom kitajskom jazyke. Moskva: Izdatel'stvo Moskovskogo Universiteta.

Sapir, Edward 1921 [1949]: Language: An introduction to the study of speech. New York: Harcourt Brace Jovanovich.

Shídài Hànyǔ cídiăn 時代漢語詞典. Hongkong: Liánbāng/Shāngwù 1982.

Visted, Øystein Krogh 2012: Nuances of Pronunciation in Chinese: Lexical Stress in Beijing Mandarin. Saarbrücken: LAP Lambert Academic Publishing. 
Xiàndài Hànyǔ cídiăn 現代漢語詞典. Hongkong: Shāngwù 1980.

Zhōu, Shàngzhī 周上之 (ed.) 2013: 世紀對話 - 漢語字本位與詞本 位的多角度研究. Beijing: Peking University Press. 
